\title{
Dual Nationality of the Ships and its Legal Impact
}

\author{
Zaid M. Aladwan \\ Law School, University of Sussex, Falmer, United Kingdom. E-mail: z.abuorabi@gmail.com
}

\begin{tabular}{l} 
ARTICLE INFO \\
\hline Keywords: \\
Convention; Flag of \\
Convenience; Nationality; \\
Sea; Shipping Law \\
How to cite: \\
Aladwan, Z.M. (2020). \\
"Dual Nationality of the \\
Ships and its Legal Impact," \\
Hasanuddin Law Review, 6 \\
(1): 109-124 \\
DOI: \\
10.20956/halrev.v6i1.2246 \\
\end{tabular}

\begin{abstract}
The international conventions for high seas had provided that each ship must have one flag only and must not change its flag during the voyage or for any reason. However, in the last years many ships have infringed this rule and had registered with other states that had allowed any foreign ships to register in their ports. These states are an open registry states, which are known as 'Flag of Convenience' states. This change of the flag during the voyage, which caused a lot of problems, was for a political and economic reasons either to make their own profit or to avoid their flag state fees. Notably, such phenomenon is considered as a maritime fraud, which will impact the maritime world and disseminate chaos on the high seas. For these reasons, this paper will highlight the duplication of the nationality for the ships issue and analyse the effects of this negative behaviour.
\end{abstract}

Copyright (C) 2020 HALREV. All rights reserved.

\section{Introduction}

Starting from the main principle in the maritime world; the freedom of seas, which means that all states have an equal right to sail their ships on the high seas whomever its owner, either individuals or companies. The High Seas Convention 1958 had recognised this principle in sub article 2(4). Ships are similar as to any estate, which must be registered to know who own it and who has the right to operate it. Therefore, the ship will become 'alive' by the registration at their original port state and by this registration it has the right to raise the flag of that state. The flag is not only a coloured piece of paper but it represents the value of that state, honour, dignity, glory, greatness and loyalty. As a result of that registration, the ship will be under control of the flag state and the ship will be an extension of the territory of that state, like their embassies, where it sails on the high seas, in case of any crime occurred on the ship or any collision occurred by their ship, they will apply their regulations, unless there are any exceptions, and the foreign regulations from other states cannot prevail over the original state regulations. 
After the Second World War, many ships had been found hoist flags for other states other than their original one in some voyages, and when they went back to their original port state they raised their original flag. This phenomenon has been described as the duplication of the nationality of the ship, although Article 92(1) of the United Nation Convention on the Law of the Sea 1982 (UNCLOS) provided that every ship must have one flag only and must not change its flag to another one, the High Seas Convention 1958 had reinforced this rule in Article 6(1), that means the duplication of the nationality is forbidden under the law. The duplication of the nationality had been encouraged by open registry states such as Panama, Liberia and Honduras, which had described as the 'Flag of Convenience' states, and what distinguished those states that they have been the biggest fleets of vessels because of this phenomenon of registration.

Duplication of the nationality of ships is a kind of maritime fraud and this phenomenon is harmful, which will have negative impact on the international maritime trade world. Meaning that many states depend on it as it forms a source of their revenue sources and the need to put an end to this negative behaviour had become priority for the maritime organisations. Indeed, the international and some domestic transactions are connected with the shipping by sea and it form an economic activity for some companies and individuals which will be disaster if this phenomenon had extended and become more acceptable for some port states.

This research will discuss the above negative behaviour and proposes a solution in order to reduce its effect before it expands to reach all maritime states. Therefore, this paper will be divided into three parts; firstly, it will clarify the definition of the above phenomenon and what are the reasons that have contributed to spread it. Part two will demonstrate the effects of the duplication and what it has affected until present day. Finally, the paper will suggest some solutions to the above matter in order to reduce the impact of this phenomena.

\section{Definition of Duplication}

The nationality of ships is the principle upon which the international maritime regime, 1 where Article 91(1) of United Nations Convention on the Law of the Sea 1982 (UNCLOS) provides that: 'every state has the right to choose their own requirements for the ships to registration and to grant its flag'. This Article have been reinforced with Article 5(1) of the High Seas Convention 1958 but unfortunately these conventions did not determine or prescribe these requirements, and as a result of that, there will be variety in these conditions between the states as some of them will impose higher standards than others. Registration of the ship has been described as '... [T]he administrative mechanism by which a state confers its nationality for the ship'. ${ }^{2}$ The registration has seen for the first time in the laws of imperial Rome, ${ }^{3}$ while in Britain, the registration system goes back to the $17^{\text {th }}$ and $18^{\text {th }}$ centuries. ${ }^{4}$ Registration is very important operation because this operation will give the flag state many rights over the

1 Tina Shaughnessy \& Ellen Tobin, 'Flags of Inconvenience: Freedom and Insecurity on the High Seas', (2006) 5 New York University Journal of International Law and Politics, 11.

2 Simon Tache, 'The Nationality of Ships: The Definitional Controversy and Enforcement of Genuine Link', (1982) 16 International Lawyer (ABA) 301, 302.

3 Proshanto Mukherjee and Mark Brownrigg, Farthing on International Shipping (4th edn, WMU Studies in Maritime Affairs, Berlin; London: Springer 2013) 201.

$4 \quad$ Ibid p. 201. 
registered ships such as confer nationality, the right to fly the national flag, ${ }^{5}$ it will be under protection by the law of that state, also the flag state has the right to exercise its jurisdiction and control in administrative and social matters over the ships. This substantial role of the flag state, as mentioned above, applicable by virtue of Article 94(1) of UNCLOS 1982 and mentioned in Article 5(1) of the High Seas Convention 1958.

After the ship has been registered in the flag state, it will acquire a certificate of registry. Article 5(2) of the High Seas Convention and Article 91(2) of the UNCLOS 1982 have provided that, which can be described as a passport for the ship. (Mukherjee and Brownrigg, 2013, p203) '... [W] [hich serves as prima facie evidence of registration and nationality of the ship. This certificate is part of the ship's documentation that is kept on board'. ${ }^{6}$ Beside the certificate of registration, the ship will also use the flag of the country where it had been registered, therefore, the ship will be subject to the flag state jurisdiction while it is within the waters of another state, and this is known as the 'extension of territory'. ${ }^{7}$ The same situation for the embassy of any country, and this will prevent other jurisdiction to prevail over it, ${ }^{8}$ as Article (97) of UNCLOS emphasise that in case of any collision or any navigational accident happened. This principle had been reinforced by the international laws by meaning that '... [S]hips are 'regarded as part of the territory of the flag state - an extension of the [registering] country', ${ }^{9}$ and this operation has been described as it is a '... [B]ridge between the ship and the mainland' and the source of vessel 'nationality'.10

\subsection{The Flag of Convenience}

As it stands in the law, the ship must not rose the flag of another state instead of its original one, and the registration with the flag state will prevent the ship to register in another state, this obligation on the flag state that it should monitor their ships and make sure that they will not change their flag. ${ }^{11}$ Article 92(1) of UNCLOS provides that ship shall only sail under one flag only. As we can understand from this Article that the dual nationality is prohibited, but in the last years after the tremendous development in maritime trade, the phenomenon of duplication of nationality has increased and spread in maritime world which had led some countries to open their harbours and to become more permissiveness with any ship wants to register with them, as they thought that it will be benefit to both parties. These countries which encourage this phenomenon are described as 'open registry',12 which is contrary to the normal situation for registry of the ships which can be described as 'closed registry'.13 Many scholars in the maritime field had adopted many names and description for these open registries. ${ }^{14}$ Notably, the most popular name is the 'Flag of Convenience' (FOC). ${ }^{15}$ In contrast, the United States prefer to call it as a 'Flag of Necessity'. ${ }^{16}$ The

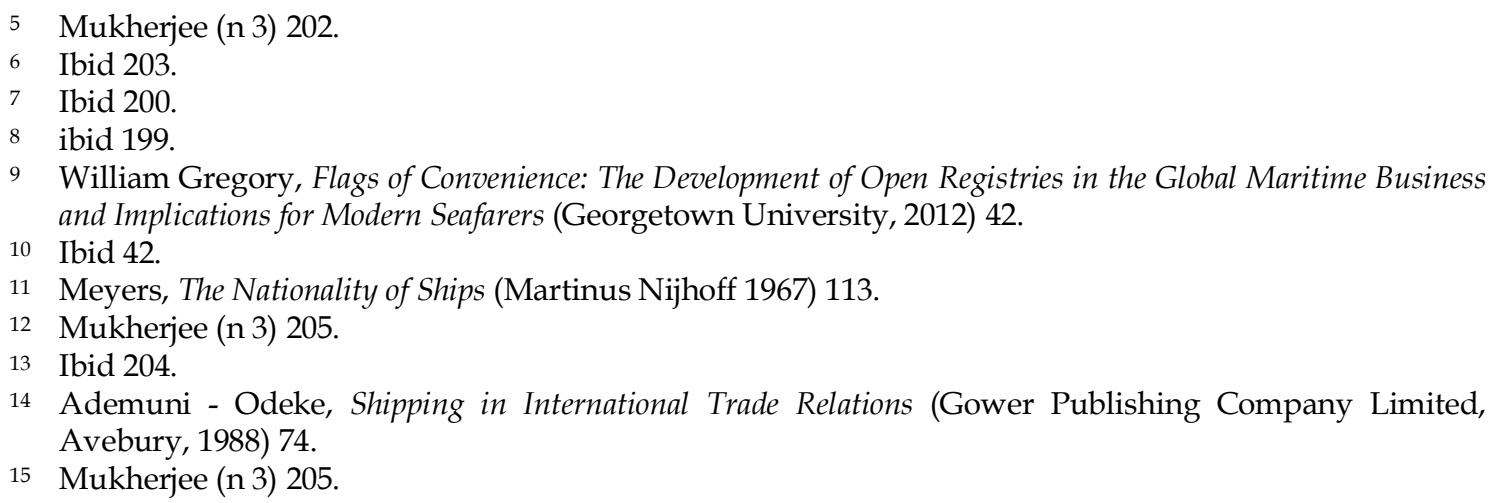


history of 'Flags of Convenience' dates back to the Roman Empire but it was not until after World War II that the desire and the need to be competitive in the world shipping markets gave rise to the spectacular growth in the use of such flags. ${ }^{17}$

Flag of Convenience is a description for the flag of any country which allows individuals or companies to register their vessels in its ports. ${ }^{18}$ Those countries are 'open registries' such as Panama, Liberia, and Honduras, as it is stated that the top registries in the world in terms of fleet size are Panama, Liberia, Marshall Islands, China-Hong Kong, the Bahamas, Singapore, Malta and Cyprus.19 Moreover, there is a list of flags of convenience countries is maintained by the International Transport Workers' Federation; the 'ITF'. ${ }^{20}$ Notably, these ships have no genuine link between these ships and with their fake flag. ${ }^{21}$ It is argued that the most satisfactory definition for these types of flags is the one adopted by the Polytechnic of Central London which was: 'A Flag of Convenience is a flag of a state whose government sees registration not as a procedure necessary in order to impose sovereignty and hence control over its shipping but as a service which can be sold to foreign shipowners wishing to escape fiscal and other consequences of registration under their own flag'. 22

\subsection{Reasons behind the Phenomenon}

There are many reasons that were behind the spread of this problem. One of these reasons was the lack of definition of the 'genuine link' where Article (91) of UNCLOS contains many conferences has discussed the genuine link but unfortunately none of them had succeed in put a definition for it. ${ }^{23}$ As a result, for registration of the ship with the flag state it must pay taxes and costs of labour to that state. Nevertheless, some ship owners argued that these cost and taxes are high comparing with the 'open registry' and argued that these taxes are extremely onerous and an impediment to their economic objectives. ${ }^{24}$ Consequently, this had push them to avoid their own state and to join these 'Flag of Convenience'. ${ }^{25}$ Owners from developed countries are more likely to choose a foreign flag than those from countries with a lower GDP per capita as higher wage rates 'scare away' the owners. ${ }^{26}$ This has been seen in the United States after the Second World War because of the high costs for trading under the United States flag. Therefore, many ship-owners had found their way to avoid these high costs by registered in the 'open registry' countries, for instance, Panama. ${ }^{27}$

The 'flag of convenience' countries' are characterized by a set of features, which are way different than the closed registry states, which might be the reasons why many ship-owners prefer them instead of their original state. For instance:

16 Alan Branch, The Elements of Shipping (4th edn, London: Chapman \& Hall 1977) 217.

17 Zoya Özçayir, 'Flag of Convenience and the Need for International Co-operation' (2000) 7(4) International Maritime Law 111, 111.

18 Stanley Sturmey, British Shipping and World Competition (Research in Maritime History NO.42, Newfoundland 2010) 177.

19 Mukherjee (n 3) 207.

20 Rodney Carlisle, 'Second Registers: Maritime Nations Respond to Flags of Convenience 1984-1998' (2009) 19 (3) Northern Mariner 319, 321.

21 Sturmey (n 18) 177.

22 Odeke (n 14) 75.

23 Gregory (n 9) 44.

24 Mukherjee (n 3) 219.

25 Gregory (n 9) 46.

26 Ibid.

27 Mukherjee (n 3) 205. 
a. These states (open registry states) allows ownership or control of its ships by noncitizens, ${ }^{28}$ which is contrary to the nationals' laws.

b. These states have a small power comparing with the closed registry states especially United States and United Kingdom, besides that, they are non-maritime states, but they can still get benefit from the maritime investments, which may produce an enormous effect on its national income, from very small charges on registration. ${ }^{29}$ Where these fees are cheap comparing with the closed registry, in Liberia, for example, the fees for registration are $\$ 1.20$ per net ton and the annual taxes are $\$ 0.10$ per net ton, these taxes fees are with guarantee for 20 years that it will not be increased. While in Honduras the registration fees are $\$ 0.25$ per net ton and the annual taxes are $\$ 0.05$ per net ton with 30 years guarantee that it will not be increased. ${ }^{30}$

c. It is argued that access to the registry is easy where a ship may usually be registered at a consul's office abroad. ${ }^{31}$ Notably, the vessel when it registered with these open registries it does not need to enter these countries, 32 or to have any business in that states, which is contrary to the national's laws for some countries which are similar between them. For instant, the United Kingdom Merchant Act $1995^{33}$ has provided that the ship-owner of a British ship, to grant the British registration, must had its principal place of business in mainland Britain or a British possession or overseas territory. ${ }^{34}$

d. These states have neither the administrative role nor the power to impose any governmental or any regulations which give the country the rights over these ships which have registered in their ports. ${ }^{35}$ This is contrary to Article 94(1) of the UNCLOS 1982.

e. The legislation of these states is soft and do not provide any special requirements for the crew or qualifications of the master and the owner. ${ }^{36}$ The lacking in such requirements had given the opportunity to any individual or company to register their ships in such states, where these open states will not require any special requirements for the registration.

\subsection{Difference in Interpretation}

As it stands in the law, ships must be registered similar to any other property such as; vehicles and real estates. It must also have one 'passport' only to enter any port. Article 92(1) from UNCLOS 1982 provides that the ship should sail under one flag only, which is the flag of the country where it had registered. Meaning that the dual flag is prohibited where it is contrary to the rule, analogy to this rule, the duplication of the nationality is prohibited. This phenomena will be considered as fraud of the main principle of the maritime navigation, where such ships should be treated as stateless. ${ }^{37}$

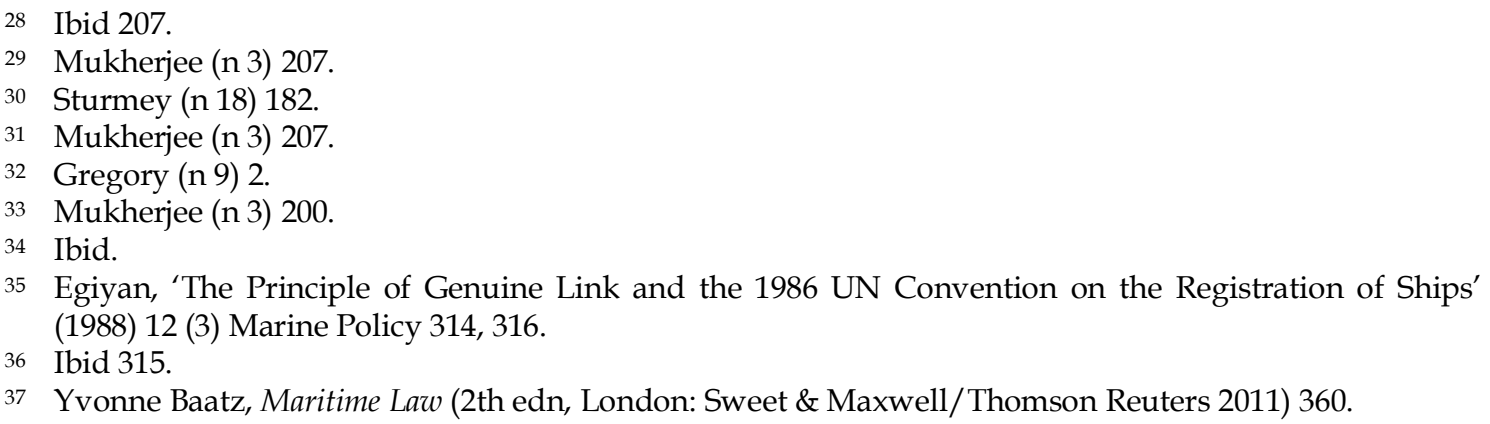


This rule has been reinforced by Article 6(1) of the Convention on the High Seas 1958, which provides: 'Ships shall sail under the flag of one State only and, save in exceptional cases expressly provided for in international treaties or in these Articles, shall be subject to its exclusive jurisdiction on the high seas.' However, some states accept the dual flag such as Cyprus but it requires proof that the original state allows such registration. ${ }^{38}$

The second paragraph of Article (6), on the other hand, concerns with navigation under more than one flag. This paragraph has been criticised by many states because it is contrary to the principle of sail under one flag only in the same Article. Arguably, that this Article made the sail under two flags or more legitimate only if this was convenience. ${ }^{39}$ In contrast, the Netherlands government did not agree with that Article, as some states said that the purpose of this article is to ensure that ships will sail under one flag only. They argued that the reason of this article is to prevent using more than one flag and in order to avoid any misunderstanding, the said Article should add these words 'using one or other as the need arises' after these words 'two or more states'. 40 The prohibition is not only for sailing under more than one flag but continue to include any attempt to change the flag during the voyage, where Article 6(1) of the convention continued and provides '... A ship may not change its flag during a voyage or while in a port of call, save in the case of a real transfer of ownership or change of registry.'

Despite of the wave of sharp criticism directed to idea of the dual nationality there is an exception of it which can be seen in case of the bareboat charterer registration. Meaning that the idea of it is that the demise or bareboat charterer has the right to register the ship under a flag of its choice. ${ }^{41}$ It is suggested that it is a temporary change of flag for the duration of the charter'.42 Arguably, the participation of two registries in the bareboat charters has created a regime of dual registration because the bareboat charter includes two parties, namely; charterer and the owner, and their states. ${ }^{43}$ Many states accepted the bareboat charterer registration such as: Antigua and Barbuda, Australia, Cyprus, France, Germany, Ghana, Guyana, Italy, Jamaica, Latvia, Liberia, Malta, Mexico, Panama, Poland, the Philippines, Spain, Sri Lanka and United Kingdom. ${ }^{44}$ Although Australia recognise the bareboat charter registration but it considered it as a new registration and, indeed, require cancellation of the first registration with the first state even if it is temporary. 45 The problem with this type of registration that there is no uniform international regime that governs it. 46

\subsection{Panama and the Duplication of the Nationality}

The maritime world after the invention of the containers has become more active and the 'open registry' states had attempt to be a part of this development, which tried to take advantage of it by permitting the registration in their harbours. Notably, statistics shows that the fleets registered under the Flag of Convenience has increased and form $53 \%$ of the world's gross tonnage. ${ }^{47}$ One of these states which has the massive effective

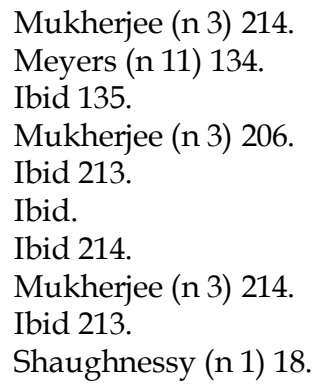


in this phenomenon is Panama. Panama had been one of the heavyweights in the maritime world where it has one of the largest ship registries in the world.48 It became a true flag of convenience state after World War II. Since this period, Panama had started writing its history of being an open access for business especially for the United States ships. ${ }^{49}$ The soft registration laws, ${ }^{50}$ geographic location for Panama ${ }^{51}$ and the Panamanian currency which was equally for the dollar at that time, ${ }^{52}$ all of these attractions were the reasons behind the evolution of such phenomenon and encourage the US ship-owners to choose Panama as their new land of registration after the World War II.

During the American Prohibition period of the 1920s, the owners of U.S ships have registered their ships in Panama in order to be able to serve liquor on the ship and sometimes to avoid the international anti-slave trade agreements. ${ }^{53}$ Further, to give the American companies the opportunity to compete in the trade.54 After United States of America, Norway has started to deal with Panama, which was a reaction to the double taxation at that time.55 After these attempts Panama has become one of the most popular state for the Flag of Convenience (FOC), beside Liberia, Honduras and other states.

Each vessel has the right to sail in the high seas but it needs to be registered first by virtue of Articles 91(1) UNCLOS and 5(1) of the High Seas Convention 1958. The variety of requirements for states to register the vessel. As a result of the defect of these Articles, have contributed to make the ships ran away from their original state and register with the Flag of Convenience states for economic and political reasons. Consequently, they raise their flag instead of their original state. This conduct is prevented by virtue of the conventions because these ships have duplicated their nationality, which is contrary to the main rule 'flying under one flag only'.

\section{The Effects of the Duplication}

In the beginning of this decade, the Flag of Convenience has started in a small limit then it had started to spread. Consequently, this expanding had effect in the maritime world as it has become a second version of registration. This phenomenon had become one of the most dangerous crises after the Second World War and made a threat to the maritime world because many ships had deviated from its original state to a foreign one, which had neither the reputation nor the experience in shipping. This deviation had changed the shipping world upside down because it has witnessed many types of fraud, smuggle and infringe regulation and laws by the ships under a pseudo flag. There are many effects from the duplication of the nationality of ships which can be

48 Chavdar Chanev, 'Cruise Ship Registry, Flag State Control, Flag of Convenience' (ShipCruise.org, February 10, 2014) <http://www.shipcruise.org/cruise-ship-registry-flags-of-convenience-flag-statecontrol/> accessed 18 th December 2019.

49 Gregory (n 9) 50.

50 Ibid 50.

51 Rodney Carlisle, Sovereignty for Sale: The Origins and Evolution of the Panamanian and Liberian Flags of Convenience (United States Naval Institute Annapolis, Maryland 1981) 2.

52 Ibid 2.

53 Shaughnessy (n 1) 16.

54 Branch (n 16) 217.

55 Carlisle (n 51) 59. 
divided to three effects: the first effect is on the crew, second effect that it will lead to a chaos in the maritime world itself and the third effect is on the marine environment. 56

\subsection{The Crew of the Ship}

The International Transport Workers Federation (ITF) had adopted many standards related to the crew as the nationality of them, besides that the closed states had requested for the registration under its laws that the nationality of the crew must be the same as the nationality of that state. Nevertheless, after the Flag of Convenience established many ships had started to infringe the state's law and avoid the ITF standards in relation to the crew nationality. Therefore, started to employ from different nationalities, thus, there will be no need to depend on the national crew and instead prefer the 'outsourcing labour'. 57

The variety of languages as a result of the multinational crew will lead to many problems as they will have a difficulty in communicate between each other. ${ }^{58}$ On the other hand, the open registry states also contravene the ITF in relation of the number of the crew where they employ fewer than required by standards, which will reflect on the safety of the ship on a bad way. For instance, in the Deutscbe Afrika-Linien, which was flying under a German flag, had employed 27 men which is less than the standards required by the ITF which was 38 men. ${ }^{59}$ As a result of employ fewer number than required on the ships, there will be lack in experience where they are unprepared or untrained to deal with the problems. ${ }^{60}$ Moreover a lack in the functional duties of the crew. Thus, if there were not enough crew to do such duties there will be overlap on the functional of them and will lead to sacrifice on the safety of the ship. Arguably, the Flag of Convenience phenomenon has contributed in decline the maritime employment in the developing states as a result of depending on foreign employee instead of national employee. ${ }^{61}$

The crew of the ship when they start their trip they do not know that this ship is sailing under a fake nationality. As a result, for working under a fake flag, their rights will be affected adversely, such as their wages, holidays, health, safety and their living conditions. ${ }^{62}$ Besides that, the crew will also have no power on the ship where everything is under the control of the owner ship. ${ }^{63}$ Arguably, after the ship owner registered his ship under the flag of convenience, the owner will reduce the salaries of the crew and will try to make more profits for his interest by this way. ${ }^{64}$ They will work under stress and besides that, their work will be busy and unscheduled. Moreover, there will not be any holidays or time to rest as all of the vessel and the crew will be under the control of the ship-owner. ${ }^{65}$

In addition, the crew will be deprived from their insurance rights in case of any accidents occurred to them and their will not be any indemnity for them or to their

56 Shaughnessy (n 1) 18.

Gregory (n 9) 4.

Mukherjee (n 3) 220.

9 Odeke (n 14) 81.

Shaughnessy (n 1) 20-21.

61 Edwen Anderson, 'The Nationality of Ships and Flags of Convenience: Economics, Politics and Alternatives' (1996) 21 Tulane Maritime Law Journal 139, 166.

62 Özcayir (n 17) 1.

63 Gregory (n 9) 39.

64 Ibid 45.

65 Chanev (n 48). 
families. This can be satisfied due to the fact that such a ship lacks authority to monitor it or to force it to do so where most of the flag of convenience states offers a few levels of protection for their ships. ${ }^{66}$ The safeness on such a vessel have less attention, which will put the crew on a dangerous situation, that will affect on their own health and their lives. Most of these harmful effects can be seen in most of the ships, which fly under the open registry flags. For instance, in Bahamas there are no codes dealing with the hours of working, holidays or the minimum salaries. ${ }^{67}$

\subsection{Chaos in the Maritime World}

After the evolution in the maritime world, the open registries states had commenced its activities and have tried to become a part of it. Many countries have been trying to be involved and to make its own effect in the world especially at shipping period. Wherefore, these states have infringed the regulation related to registration and had made a chaos in oceans and seas by relaxation of its regulations, which allowed any foreign vessel to registered in their ports. This fact had driven such vessels to stay away of their original states and to register under the Flag of Convenience states. In this regard, the unethical legal fictions designed to escape the safety controls, social legislation, taxation, and maritime policies required by other nations. ${ }^{68}$ Those open registry states besides the revenue and the income that will gain by letting the foreign vessels to register with them, even without entering their ports back again, it will establish its own position on the maritime world and will draw its own image on the sea world. 69

In the last years many ship-owners try to avoid their original regulations and had registered their ships in foreign states due to the fact that open registries regulationsimposed taxes and registration fees which are less than the closed registries. For instance, some British companies registered their ships in Hong Kong because it has imposed some cheap fees at that time comparing with the British fees. ${ }^{70}$ Arguably, the closed registry states are afraid that the preparation of their fleets will decrease because of the second version of registration, which encourage the ship-owners to register their ships with the open registry states. ${ }^{71}$

Moreover, the ship-owners, had found in the open registers states their shelter in the illegal actions because their states; the original states for the ships, were very strict comparing with the open registries. For instance, the United States regulations had prevented their ships to carry an alcohol, so they had to register their ship under the Flag of Convenience states to avoid such a rule. ${ }^{72}$ Another example can be seen, in the nineteenth century the slavery was forbidden and it's an illegal act, Article (13) of the High Seas Convention 1958 had emphasise it, yet some American ships had re-flagged their ships by registration with the open registry states and fly their flag, then they had started to trade in slaves to avoid the antislavery rules. ${ }^{73}$

66 Gregory (n 9) 48.

Chanev (n 48).

68 Shaughnessy (n 1$) 18$.

69 Elizabeth Desombre, Flagging Standards: Globalization and Environmental, Safety and Labour Regulations at Sea (MIT Press Books, 2006) 210.

70 Sturmey (n 18) 177.

71 DeSombre (n 69) 218.

72 Mukherjee (n 3) 205.

73 Shaughnessy (n 1) 16. 
More importantly, after the invention of the containers many attempts to smuggle has been noticed. This can happen by smuggle the individuals, who stayed in the container all the shipping voyage, that fly under the fake flag ships. In one story, about sixty Chinese people has been found in containers in an American vessel after it had been loaded from another ship. ${ }^{74}$

Beside smuggling and infringement of the law, the duplication of the nationality had also caused an appropriate environment to terrorism. That is to say, many unknown ships, which are flying under a fake flag, can enter any state by pretext of trade which can be hidden some terrorist in the ship especially after the foundation of containers. For instance, they can attack some valuable targets in the seas which are property for other countries. ${ }^{75}$ The Flag of convenience phenomena can also support the illegal trade which related to terrorism such as selling and buying weapons for some terrorist organizations such as Al-Qaida. ${ }^{76}$

On the other hand, the open registries states enjoy attractive beautiful cities which attract the tourist, thus, through this 'new version of registration' will reflect adversely on their reputation where this conduct will encourage tourists to avoid these countries, consequently, reduce the profit of the tourism as a revenue for the state. Further, this will reduce the percentage of importation and exportation between these states and others, thus; decrease the economic status for the state. Arguably, the ownership of a ship that fly under two flags will have more freedom than other ships, as it will not be under control of the states to join the war.77 That is to say, such a ship cannot be trusted or at least the states cannot know that if it's their ship or not, this can be a doubleedged weapon for the duplication nationality.

\subsection{Environmental Pollution}

The pollution of the environment has always been a huge topic that many organisations all over the world were concern about and the pollution over the seas was one of these issues. The attention of the sea's pollution has increased after the evolution on the maritime world. No one has noticed how much the ships effect on the pollution by the gases rising from burning fuel for the operation of ships. In this regard, many ships found in the oceans their shield to dispose of its spoiled commodity, instead of recycle it or dispose it in another areas. Consequently, no attention to aquatic life such as fish, sharks, dolphins and Coral reefs ... etc.

After the Flag of Convenience has established and become desirable for many shipowners, the number of ships in the seas has increased. Many statistics showed that most of these ships has caused a lot of problems in the seas related to pollution by abuses the using of shipping in trade due to the lack of the regulations, the poor quality of the ships and the untrained crews. ${ }^{78}$ Observably, the open registries states were responsible for the marine pollution in the world. ${ }^{79}$ Many ships tried to import a large amount of oil on its ships and due to the poor quality of these ships, many of them had sank in the ocean while it was carrying oil on it which caused a pollution damages. In the 1978, the $M / V A M O C O C A D I Z$ was carrying oil on it, unfortunately it

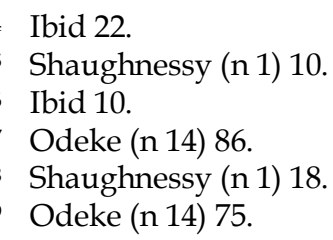


has sunk. The US court of appeal had found that the unqualified crew on this ship, which was flying under the Liberian flag, was the reason of this occasion. ${ }^{80}$ Another occasion, in the 1967 the TORREY CANYON has also wrecked in the British Cornish coast while it was carrying oil on it which had led to leak the oil to the sea. ${ }^{81}$ After these disasters, the reputation of Liberia has become shaky and other states has become confused about dealing with their ships. In the following years, the number of the oil spilling accidents has increased due to the increasing of number of ships flying under the open registries' flags. In regard to such fact, it pushed the environment organisations to claim to boycott these open registry states.

Beside the pollution, the environment organisations have lost a lot of money in cleaning up the mess by the wrecked ships. Nonetheless, due to the lack of the uniform regulations and authorities, no sanctions can be imposed over the states that was such ships sailing under their flags. The fishing sector is another victim of the phenomenon of the dual nationality ships where many organisations had tried to manage the fishing operation on the high seas. In this regard, these fisheries organisations had put measures to organise these operations and these measures were only applicable over the states which are member of the organisation. ${ }^{82}$ After the establishment of the open registry system, many vessels had joined these organisations under fake flags which had led to an over-exploitation of fish stocks in some regions such as Northwest Atlantic and the Southern Ocean. 83

After these problems, which had affected on the maritime world, many voices had risen to attack the second version of registration and to put strict measures to these states that support the fake nationality for ships to make its own profits. If such states had continued what it believes in, there will be crevice and variance in the working class of the seafarers in the closed states and the open ones. Moreover, the shipsowners will refuge to the open registry ports to commence their private enterprise and they will have more freedom to sail in the high seas. Therefore, it will lead to a massive chaos in the shipping era and to an assault on the rights of other countries. Thus, the questions are, to what extend these open registry states will remain enjoying freedom in the maritime world and when will be the appropriate time to direct the knockout blow to these countries?

\section{Legal Solutions}

Starting from the effects that have been noticed in above, it has become very important to stop the expanding of the phenomenon of the dual nationalities for ships. This bad conduct impacts on the marine world adversely, where the duplication of the nationality is considered as a maritime fraud. Therefore, it is necessary to provide protection for the interests of states in business transactions where it is connected with the shipping by sea. It had become necessary to find solutions for this negative behaviour by the open registries' states. During the last years, many organisations had tried to put solutions for the Flag of Convenience states but unfortunately did not pass to achieve its goals. Thus, to stop this phenomenon this section will propose some

80 Anderson (n 61) 162.

81 Carlisle (n 19) 321.

82 Robin Churchill, "The Meaning of the "Genuine Link" Requirement in Relation to the Nationality of Ships' (2000) A Study prepared for the International Transport Workers' Federation University of Wales, Cardiff, 62.

83 Ibid 62. 
solutions. These propositions can be divided into three propositions; firstly, the need of a uniform conventions and regulations, secondly the cooperation between states and maritime organisations to stop this problem and finally the need for strict measures and deprive ships from some advantages.

\subsection{Unify Conventions and Regulations}

Pursuant to the principle of 'Freedom of Seas', which was mentioned in Article 2(4) of the High Seas Convention 1958, many vesicles can access the sea. Therefore, to avoid any misunderstanding between the national laws and because of the fear of the abuse of the rights under the high seas, there had to be a uniform regime of conventions and regulations for ships. The first attempt to unify the laws was in 1958 by the United Nations Convention on the Law of the Sea (UNCLOS). In 1960, which had failed to deal with the issues arose at that period consequently there had the need to a new version of the (UNCLOS). This happened in 1982, which is still applicable today. Another convention that deals with the high seas is the Convention on the High Seas 1958. Unfortunately, these conventions, where had been seen as comprehensive at that period, have many criticisms in relation to some issues and some Articles.

Notably, in Article 91(1) of UNCLOS 1982 and in Article 5(1) of the High Seas Convention 1958, both had stipulated that each state have the right to determine its requirements to any ships that want to grant its nationality by registration with them. Yet, both articles did not describe or identified these requirements, which led to a chaos in registration the ships. Each country has the freedom to choose its requirements, consequently, there was disparity between the requirements of the states. ${ }^{84}$ This disparity of the requirements had pushed some ships to ran away from their original ports and to refuge to the open registry states to register their ships where their laws are more relaxed than their original states. Sometimes, more 'complex' conditions are required, e.g. the number of the crew, who must have the same nationality with that state, or a specific quality for the ships or equipment that should be on the ship. However, some ship-owners do not have such requirements, thus; they will refuge to the open registries to grant its nationality then they can commence their own business.

Another defect has been found in the same Articles in the conventions is the need of the existence of a genuine link between the registered ships and the flag states. The previous Articles insisted on that link but none of them had defined what is the meaning of such a link or how can such a link be established. Arguably, the unsafe of the maritime world was because of the lack of the genuine link required in the conventions which give the unknown ships the freedom to sail in the oceans and seas. ${ }^{85}$ Consequently, the first solution to avoid the phenomena of FOC is that the UNCLOS 1982 and the High Seas Convention 1958, which must be amended and must be more precise in regard to the registration requirements and the genuine link. If the genuine link is defined, states must exercise its jurisdiction to monitor and control over its ships and to ensure that the genuine link is still exist and enforced on their vessels. It is suggested that the enforcement of the genuine link can be done by establish maritime inspection offices all over the states and these inspection offices will be responsible for the safety in oceans and seas. ${ }^{86}$ Cyprus has started to establish the inspections offices

84 Odeke (n 14) 68.

85 Anderson (n 61) 165.

86 Tache (n 2) 312. 
idea to fix its bad reputation, where it was been mentioned as it is one of the Flag of Convenience states. These inspection offices were effective and have achieved their goal because it has contributed to put Cyprus in the right way. ${ }^{87}$ However, against this suggestion if the genuine link will exist between ships and their flag states this will decrease the depend on the foreign crew for some ship-owners. ${ }^{88}$ Meaning that the foreign crew will be useful for the ship where some of them are talented and have experience contrary to some national crew. In short, the need for a new 'constitution' for the high seas is necessary to destroy the ghost of the duplication nationality issue.

\subsection{The Cooperation between States and Maritime Organisations}

Another solution can be proposed to stop this phenomenon is by the utmost cooperation between the port states and the maritime organisations. Through this cooperation, the registration of the ship will be more logical and the safety standards will be more obvious where these bodies will try to make the ships more careful about the standards. Maritime organisations are required to establish inspection offices in all over the globe. These inspection offices will monitor over the registered ships and will ensure that all the requirements are correct and available. ${ }^{89}$ Through these inspection offices, the genuine link can be established. For instance, if the vessel, which want to register, failed to comply with the requirements, these offices will give the said vessel a time limit to fix the requirements or it will the right to register will prevent. The responsibility of these offices will not be only on registration but it will have control over the ships too. That is to say, every period the owner-ship or the master, in behalf of the owner-ship, must give the inspection office a weekly log includes all the voyages for the ship that it had went for and all the voyages that it will go in the next period.

On the other hand, the location of the ship during the voyage and the voyage log will be transferred to other offices all over the globe. Through technology, everything can happen. For instance, through inserting a chip in the vessel, hence, these offices will cooperate with other offices in other states to ensure that no ship will re-flag its flag during the voyage or at any time. Through this solution, the port states will know when any ship enter the open registry states and when it will depart. Therefore, if the ship continues responding for the log details that means it had not changed its flag, otherwise the ship had been re-flagged. As a result, it will be in the black list and the maritime organisations will issue a detention order for such a ship for the port states.

Further, these inspection offices will have the right to detain any suspected vessel or any vessel that has infringed the regulations of any state. The International Transport Workers Federation (ITF) has been always concerned about the Flag of Convenience issue and tried to adopt many solutions against this negative behaviour. In the 1958, it had started to boycott the open registry states and asked for the genuine link to be established. Initially, it had made some success yet, this campaign did not make any effective results. ${ }^{90}$

In short, the responsibility is not only on the flag state or on the maritime organisations, it is the world responsibility. This issue effect on all the marine world,

87 Esme Palas, 'Cyprus flag: A flag of Progress and Quality' (All about Shipping.co.uk 8th July 2013) $<$ http:// www.allaboutshipping.co.uk/2013/07/08/cyprus-flag-a-flag-of-progress-and-quality/> accessed $4^{\text {th }}$ December 2019

88 DeSombre (n 69) 84.

89 Shaughnessy (n 1) 28.

90 Anderson (n 61) 166. 
thus; the need of the cooperation is necessary and important to defeat this virus and to give the oceans its stability in a time where the sailing on the high seas have become very dangerous.

\subsection{The Need for Strict Measures}

After the duplication nationality for ships have become a bad influence on the marine world, there must be some strict measures that it will prevent any more ships to re-flag its flag, in order to to minimize the spread of the phenomenon. Some of these sanctions can be suggested. Notably, most of the sanctions by domestic laws are applicable against the individuals and not over the ships itself. ${ }^{91}$ If some sanctions are imposed against the ships, it will be more effective because the percentage of the fake ships will decline. These measures over the ship can be like detention the ship in the port state depending on the correspondence between the inspection's offices.

On the other hand, the port states have the authority to prevent any ship to leave its port if the ship has been suspected to be a fraud one. Moreover, there will be sanctions against the individuals e.g. pay fine in case of they have been operated a ship which had a dual nationality. Meaning, these individuals will be prevented to operate any ship anymore or to have any business related to ships.

Other solutions that can be suggested, such as; the boycott against the open registries states and to prevent them to join any maritime organisations, thus, they cannot benefit from any advantages from these organisations. These ships will be inserted under blacklisted ships, which will be prevented to enter any port and it will be boycott from all the port states and organisations.

Further, some suggestions can be accepted but in a narrow scope. For instance, the dual nationality can be acceptable in some exceptions but it will be deprived from some advantages, such as the maritime insurance. Consequently, if any vessel wants to change its registration, it can sail under a foreign flag it will not be insured. Other suggestion, if such a ship want to duplicate its nationality, it must waiver of its original registration and waive its original flag in favour of grant the new nationality and the flag. Arguably, if such solution accepted, the chaos in the maritime world will continue as it will affect on the business and the reputation of some states, as the amount of their fleets will reduce in favour of registration with other states.

In short, the duplication nationality is a virus that had affect the maritime domain, at both internal and external. If such a phenomenon persists to expand, it will destroy one of the most effective pillars in the international transactions where it can be described as 'the blood' of the transactions. Therefore, these proposed solutions must be activating all together in order to eliminate this virus.

\section{Conclusion}

The international regime was focusing in united the rules related to shipping on the high seas but it was not comprehensive. The duplication of the nationality for ships phenomenon has arises due to the lack of united regulations. This issue that had given profits to the open registry states had been one of the most crisis in the nineteen century and continued to increase until it become more preferable for many companies and individuals these days to make their own profits. The need of to be aware of this negative behaviour is necessary to stop the crawling for it. Starting from the

91 Meyers (n 11) 183. 
regulations and conventions ending with the port states. This phenomenon must be the main topic of the news where many states do not know about at or they do not know the main factors that have contributed on it. Carriage of goods by sea is the hub of the international economic, consequently this dual nationality is a negative action, which will reduce the accreditation on this method of transportation. Simply because many states and investors would be afraid of the shipping and the transportation by ships will be kind of risk for them. Because none of them want to deliver their goods to the ship someday then the next day they will wake up on the news of disappearing their ship.

The open registry states, which are the central point of the duplication nationality, must boycott and the maritime organisations must prevent any transactions from any port states or vessel with them until they fix their strategy of registration. There is no need to be afraid of the technology as it should be helpful to eliminate many crises these days, which can establish a solid protection system through monitor the ships. Further, establish records for them, where the details about the ships can transfer from a port state to other as fast as possible. The need for a genuine link is the main aim for the maritime organisations in order to establish a real relation between the port states and the ships that have registered with them. The absence of such linkage had led to establish the second version of registration for some countries. To sum up, the dual flag is not the issue for the states only, it is an issue that will impact on the whole world, individuals, companies, governments, organisations and institutions. Therefore, the sounds that asking for relief must be heard to eliminate this virus. Consequently, all of the maritime organisations must rapid and immediate intervention to eliminate the danger on the horizon before this phenomenon continues to expand.

\section{References}

Ademuni - Odeke, (1988). Shipping in International Trade Relations, Gower Publishing Company Limited, Avebury.

Chavdar Chanev, 'Cruise Ship Registry, Flag State Control, Flag of Convenience' (ShipCruise.org, February 10, 2014) <http://www.shipcruise.org/cruise-shipregistry-flags-of-convenience-flag-state-control/> accessed 18 ${ }^{\text {th }}$ December 2019.

Edwen Anderson, (1996). 'The Nationality of Ships and Flags of Convenience: Economics, Politics and Alternatives' 21 Tulane Maritime Law Journal 139, 166.

Egiyan, (1988). 'The Principle of Genuine Link and the 1986 UN Convention on the Registration of Ships' 12 (3) Marine Policy 314, 316.

Elizabeth Desombre, (2006). Flagging Standards: Globalization and Environmental, Safety and Labour Regulations at Sea, MIT Press Books.

Esme Palas, 'Cyprus flag: A flag of Progress and Quality' (All about Shipping.co.uk 8th July 2013) <http://www.allaboutshipping.co.uk/2013/07/08/cyprus-flag-a-flag-ofprogress-and-quality>> accessed $4^{\text {th }}$ December 2019

Proshanto Mukherjee and Mark Brownrigg, (2013). Farthing on International Shipping (4th edn, WMU Studies in Maritime Affairs, Berlin; London: Springer.

Robin Churchill, (2000). 'The Meaning of the "Genuine Link" Requirement in Relation to the Nationality of Ships' A Study prepared for the International Transport Workers' Federation University of Wales, Cardiff. 
Rodney Carlisle, (1981). Sovereignty for Sale: The Origins and Evolution of the Panamanian and Liberian Flags of Convenience (United States Naval Institute Annapolis, Maryland.

Rodney Carlisle, (2009), 'Second Registers: Maritime Nations Respond to Flags of Convenience 1984-1998' 19 (3) Northern Mariner 319, 321.

Simon Tache, 'The Nationality of Ships: The Definitional Controversy and Enforcement of Genuine Link', (1982) 16 International Lawyer (ABA) 301, 302.

Stanley Sturmey, (2010), British Shipping and World Competition (Research in Maritime History No. 42, Newfoundland.

Tina Shaughnessy \& Ellen Tobin, 'Flags of Inconvenience: Freedom and Insecurity on the High Seas', (2006) 5 New York University Journal of International Law and Politics, 11.

William Gregory, (2012), Flags of Convenience: The Development of Open Registries in the Global Maritime Business and Implications for Modern Seafarers, Georgetown University.

Yvonne Baatz, (2011). Maritime Law (2th edn), London: Sweet \& Maxwell/Thomson Reuters.

Zoya Özçayir, (2000). 'Flag of Convenience and the Need for International Cooperation' 7(4) International Maritime Law, 111.

\section{Conflict of Interest Statement:}

The author(s) declares that the research was conducted in the absence of any commercial or financial relationships that could be construed as a potential conflict of interest.

Copyright (C) 2020 HALREV. All rights reserved. 